\title{
DETERMINATION OF OPTIMUM MANAGEMENT STRATEGY FOR HONEY PRODUCTION FOREST LANDS USING A'WOT AND CONJOINT ANALYSIS: A CASE STUDY IN TURKEY
}

\author{
GÜNGÖR, E. \\ Bartın University, Faculty of Forestry, 74100 Bartın, Turkey \\ e-mail: egungor@bartin.edu.tr; phone: +90-5-326-283-318; fax: +90-3-782-235-069 \\ (Received $11^{\text {th }}$ Mar 2018; accepted $21^{\text {st }}$ May 2018)
}

\begin{abstract}
In this study, it was aimed to develop alternative management strategies for Honey Production Forest (HPF) lands, which are planned to be set up in Bartin, and to select the optimum one. For this, a model (A'WOT-CJA), in which A'WOT (SWOT-Analytical Hierarchy Process) and Conjoint Analysis (CJA) are used together, was developed within the framework of ecological, social and economic criteria based on the participation principle. Within the scope of A'WOT-CJA, the honey status of Bartin was determined by SWOT in the first step and it was prioritized using AHP by digitizing in the second step. The highest SWOT values found as a result of AHP are "honey type" with 0.245 in terms of strength, "honey production season length" with 0.202 in terms of weakness, "bee product type" with 0.224 in terms of opportunity and "beekeeping type" with 0.147 in terms of threat. However, in order to improve the effectiveness and comprehensiveness of the strategies, 81 strategies with four factors, each consisting of three levels, were developed and evaluated by CJA in the third step. However, since it was difficult and time consuming to prioritise these 81 strategies, these strategies were reduced to 9 through orthogonal rotation and were arranged to be 110 participants among those related to the subject (50 people from the local population, 10 people from public institutions, and 50 people from NGOs). According to the A'WOT-C results, HPF optimum management strategy of Bartin Province was formed as follows; "In the establishment of honey forests, giving priority to the chestnut species with high economic return, putting the lands, where the honey production season will last at least six months, forward in land selection, preparing the lands especially to increase the honey and royal jelly yield and the lands being in such form to support migratory beekeeping."
\end{abstract}

Keywords: forest management, beekeeping, participation, multi-criteria decision-makings, rural development

\section{Introduction}

The necessity of using the natural resources effectively and efficiently in consideration of increasing population, needs and expectations refers to a precise equation in today's world and human being is the basis of this equation. Planners and implementers endeavour to meet the ever-changing and evolving needs. This process also increases the expectations for natural resources.

Although the fuel wood and timber are the most known among the resources obtained from the forests, the non-wood forest products (NWFP) are the most common products obtained from forest resources. Within the scope of plant-derived non-wood forest products in Turkey, apicultural products and honey have important roles as well as wild food plants, medical and aromatic plants, bulbous plants, dye plants and mushrooms (HFAP, 2013). Forest resources also provide an important input to apicultural products with their rich biodiversity and gene resources.

Forests are important resources for the production of quality honey (HFAP, 2013). Furthermore, while forests provide a low investment environment for beekeeping activities, they create high income opportunity with the labour force input and constitute an important source of income for forest villagers (Yilmaz, 2006; Gungor and Ayhan, 
2016). In addition, they make significant contributions to reduce the rural-urban migration and ensure community stability with the influence of income (Yilmaz, 2006). When viewed from this aspect, it can be stated that beekeeping is one of the most important rural development instruments (Korkmaz et al., 2015). On the other hand, while forests contribute to honey production, they also help pollination and soil conservation and they fulfill an important function at the point of conservation and development of biodiversity (HFAP, 2013).

Honey and apicultural products produced together with honey such as propolis, royal jelly, pollen and beeswax have an important place in world trade. Today, there are around 59 million bee hives in the world and around 1 million 250 thousand tonnes of honey is produced from them. India is the country with the highest number of hive assets in the world (12 million hives). Nevertheless, China, which has 9 million hives, is the country that produces the biggest amount of honey (466.6 thousand tonnes) in the world. After China, Turkey (94.7 thousand tonnes), Iran (74.6 thousand tonnes), Ukraine (73.7 thousand tonnes) and Russian Federation (68.4 thousand tonnes) come respectively in terms of honey production (Figure 1) (FAO, 2018). As can be understood from these statistics, Turkey is the second most important honey producer of the world.

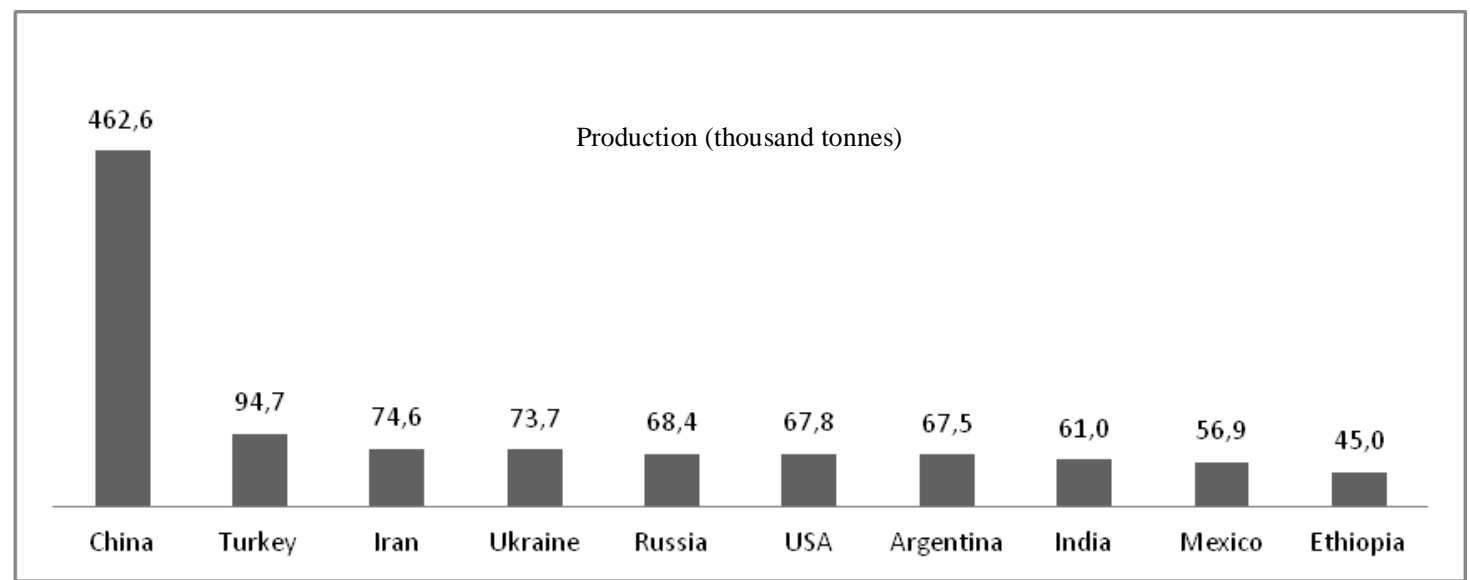

Figure 1.World's 10 largest honey producers (FAO, 2003)

The average honey production per hive is around $22 \mathrm{~kg}$ in the world. Canada (56 $\mathrm{kg} / \mathrm{hive}$ ), China (52 kg/hive), Mexico (39 kg/hive), Argentina ( $27 \mathrm{~kg} / \mathrm{hive}$ ) and the USA (26 kg/hive) are the countries that carry out honey production above the world average. Turkey is considerably lower than the world average with the production value of 15 $\mathrm{kg} /$ hive (ranks number 12) (FAO, 2009, 2018). Although $75 \%$ of honey plant species and varieties, which are available in the world, are available in Turkey (HFAP, 2013), Turkey does not yet have a sufficient role in the world honey trade, as the honey yield per hive is below the world average (OCEP, 2013).

On the other hand, forest areas in Turkey cover the 27.6\% (21.678.134 ha) of the area of the country (Table 1). The areas, where there are forest trees and shrubs such as chestnut, tilia, acacia and rhododendron, which can be used as honey forests, form about $4 \%$ of the forest areas (GDF, 2015). When forest gap inside the forests are added to these areas, it is understood that Turkish forest areas have sufficient potential for Honey Production Forests (HPF). 
In order to increase honey production yield and to establish sustainable honey forests, the areas, where forests are to be established, should be determined with a participatory approach by taking the social demands and resource constraints into consideration. For this reason, interest groups should be included in the planning process during the process of determining the optimal management strategy of HPF. Through the HPFs to be planned in this way, the forests will be capable of providing many ecological-environmental, economic and socio-cultural benefits as well as the yield increase.

Effective strategies should be developed and implemented at the determination, management and planning stages of HPF lands in forests due to the contributions of beekeeping and apicultural products. There are number of examples of forest products and services in the world that are integrated into management strategies (Leuschner, 1992; Clutter et al., 1992; Duerr, 1993; Klempeer, 1996; Martell et al., 1998; Carsjeans and Vanderknaap, 2002; Eastman et al., 1998; Yilmaz, 2004; Gungor, 2005; Sen and Gungor, 2018).

Food safety, which has become even more important with the increase in world population, and the production of honey and other apicultural products within this context (FAO, 2009), have become one of the ultimate goals that should be achieved for Turkish forestry (GDF, 2015). However, the studies conducted to increase honey production are not carried out by scientific methods but by the initiatives of decision makers. Within this scope, it was aimed to develop alternative management strategies for the planning of HPF sites using multi-criteria decision making methods and to select the most suitable HPF site by prioritising the alternatives.

\section{Study area}

Bartin Province, which is the study area, is located in the Western Black Sea region of Turkey between $41^{\circ} 53^{\prime}$ northern latitude and $32^{\circ} 45^{\prime}$ eastern longitude (Figure 2). Its surface area is $2,143 \mathrm{~km}^{2}$. In Bartin, mild marine climate (Black Sea Climate) with warm $\left(26^{\circ} \mathrm{C}\right.$ and over) summers and cooler winters $\left(-2{ }^{\circ} \mathrm{C}\right.$ and below) prevail (BMST, 2017). The fact that it is close to the sea and that the mountain ranges, which are not very high, are parallel to the shore causes the temperature differences on the coastline to decrease and humidity to increase (BG, 2017). For this reason, Bartin Province has an important potential of honey production in terms of its geographic location and climate. The general area of Bartin Province is 228,576 ha. The forest area is 135,437 ha and the forest area ratio of the province is $59.3 \%$. This value is above the average of Western Black Sea (50\%) and the country (28\%) (GDF, 2015). Bartin Province has an important potential of honey production in terms of its forest area values.

Bartin is one of the significant regions in terms of potential honey production areas due to its rich biodiversity in the Black Sea region, its edaphic and climatic conditions, for having tree species with high nectar yield such as chestnut, tilia and false locust etc. (GDF, 2011; WWF, 2003, 2010; Gungor and Ayhan, 2016).

On the other hand, in terms of honey production, forest area, general area, number of forest villages, population, general population and number of hives of Bartin Province and region and country values are given in Table 1 (Gungor and Ayhan, 2016). 


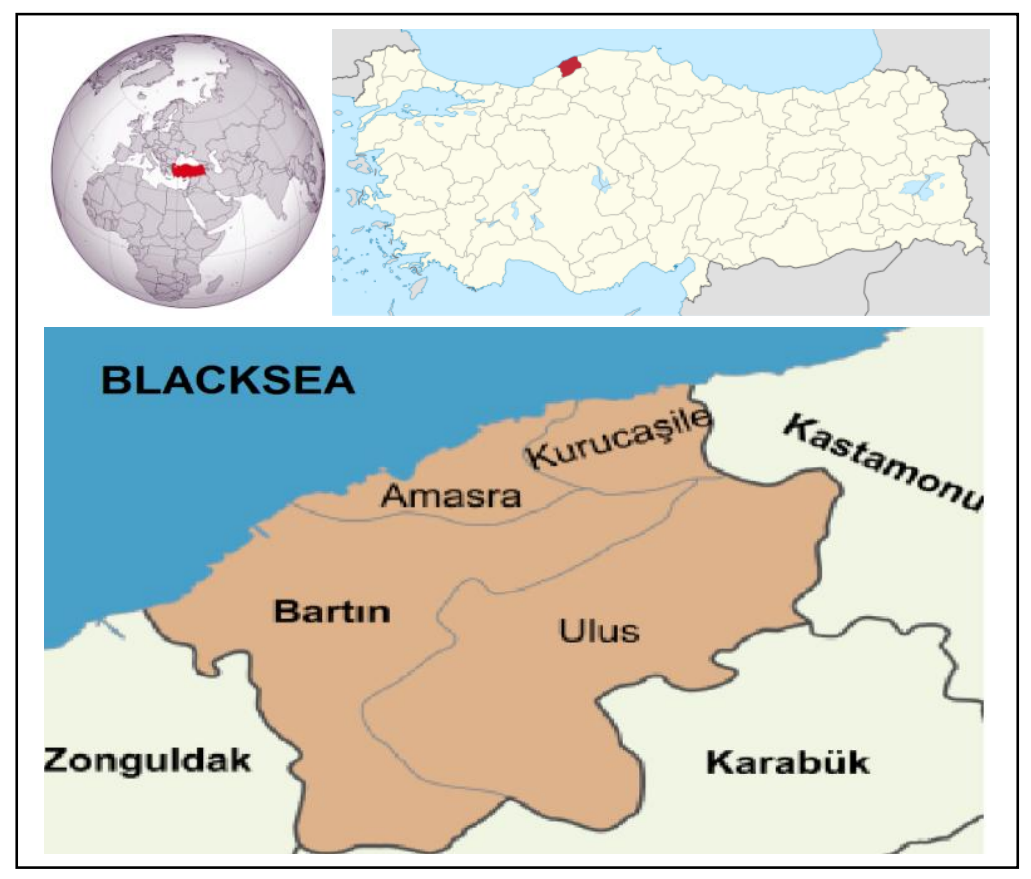

Figure 2. Geographical location of Bartin Province

Bartin Province, which has a high portion of forest assets, is also well above the country average in terms of forest villager density. Therefore, Bartin Province, which has an important potential for honey production, is well below the country and the region average in terms of honey yield level (Table 1). As can be understood from these statistics, Bartin Province could not tip the scales in its own favour in honey production.

Table 1. Comparison of forest area, general area, number of forest villages, population, general population and number of hives of Bartin Province with region and country values

\begin{tabular}{|c|c|c|c|c|c|c|c|c|c|c|}
\hline \multirow{2}{*}{\multicolumn{2}{|c|}{ Region Provinces }} & \multicolumn{3}{|c|}{ Area Information $^{(1)}$} & \multicolumn{3}{|c|}{ Population Information $^{(2)}$} & \multicolumn{3}{|c|}{ Honey Production Values } \\
\hline & & $\mid \begin{array}{c}\text { Forest Area } \\
(\mathrm{Ha})\end{array}$ & \multirow[t]{2}{*}{$\begin{array}{c}\text { General } \\
\text { Area } \\
(\mathrm{Ha})\end{array}$} & $\begin{array}{c}\text { Forest } \\
\text { Area/ } \\
\text { General } \\
\text { Area } \\
(\%)\end{array}$ & $\begin{array}{c}\text { Forest } \\
\text { Villagers } \\
\text { (Person) }\end{array}$ & \multirow[t]{2}{*}{\begin{tabular}{|c|}
$\begin{array}{c}\text { Total } \\
\text { Population } \\
\text { (Person) }\end{array}$ \\
271208 \\
\end{tabular}} & \begin{tabular}{|c} 
Forest \\
Villagers/ \\
General \\
Population \\
$(\%)$
\end{tabular} & $\begin{array}{c}\text { Number of } \\
\text { Hives }^{(3)} \\
\text { (Piece) }\end{array}$ & \multirow[t]{2}{*}{\begin{tabular}{|c|}
$\begin{array}{c}\text { Honey } \\
\text { Production } \\
\text { (T) }\end{array}$ \\
260
\end{tabular}} & $\begin{array}{c}\text { Honey Yield } \\
\text { (Kg/Hive) }\end{array}$ \\
\hline \multirow{6}{*}{$\begin{array}{c}\text { Western } \\
\text { Black Sea }\end{array}$} & Bolu & 514295 & & 64 & 78849 & & 29 & 22645 & & 11 \\
\hline & Duzce & 119420 & 243411 & 49 & 85728 & 338188 & 25 & 36164 & 518 & 14 \\
\hline & Zonguldak & 156586 & 385604 & 41 & 199013 & 619703 & 32 & 38892 & 124 & 3 \\
\hline & Bartin & 110227 & 199491 & 55 & 72260 & 187758 & 38 & 25587 & 352 & 14 \\
\hline & Karabuk & 116804 & 129980 & 90 & 43466 & 227610 & 19 & 19222 & 248 & 13 \\
\hline & Kastamonu & 477316 & 1250775 & 38 & 160724 & 361222 & 44 & 59419 & 418 & 7 \\
\hline \multirow{2}{*}{\multicolumn{2}{|c|}{$\begin{array}{c}\text { Western Black Sea } \\
\text { Sum } \\
\text { Western Black Sea } \\
\text { Mean } \\
\end{array}$}} & 1494648 & 3015465 & & 640040 & 2005689 & & 201929 & 1920 & \\
\hline & & 249108 & 502578 & 50 & 106673 & 334282 & 32 & 33655 & 320 & 10 \\
\hline \multirow{2}{*}{\multicolumn{2}{|c|}{$\begin{array}{l}\text { Black Sea General } \\
\text { Sum } \\
\text { Black Sea General } \\
\text { Mean }\end{array}$}} & 6727514 & 11483861 & & 1830241 & 7539694 & & 1318876 & 22313 & \\
\hline & & 373751 & 637992 & 59 & 101680 & 418872 & 24 & 73271 & 1240 & 17 \\
\hline \multirow{2}{*}{\multicolumn{2}{|c|}{$\begin{array}{c}\text { TURKEY Sum } \\
\text { TURKEY Mean }\end{array}$}} & 21678134 & 78534470 & & 7073020 & 76667864 & & 6348009 & 94694 & \\
\hline & & 267631 & 969561 & 28 & 87321 & 946517 & 9 & 78370 & 1169 & 15 \\
\hline
\end{tabular}

(1) GDF, 2014, (2) TBMM, 2010, (3) OCEP, 2013, (4) TUIK, 2017. 


\section{Materials}

Data necessary to realize the study aim is obtained from various public institutions, non-profit organizations and literature. Within this scope, Management Plans by the Forestry Operation Directorate of Bartin (FODB) (FODB, 2005), Honey Forest Action Plan (HFAP) by the General Directorate of Forestry (GDF) (HFAP, 2013) and Bartin Honey Forest Project (BHFP) (BHFP, 2013) were utilized. Moreover, the statistical data of the state institutions and organizations (TBMM, 2010; BAKKA, 2011, FAO, 2018, TUIK, 2017) and the Honey Forest Projects (GDF, 2012a; 2012b; 2014) conducted in various provinces and scientific research studies conducted in the region (Genc, 2003; Tutkun, and Bosgelmez, 2003; Misir, 2011; Dogaroglu, 2017; Bekar and Acar, 2017; Gungor and Sen, 2018; Sen and Gungor, 2018) were also utilized within the scope of this study. In addition, the records of Turkish Association of Beekeepers (TAB) (TAB, 2017) and Beekeepers Association of Bartin (BAB) (BAB, 2017), which is connected to this centre, were also used within the scope of the study together with the employers of association and the local public talks.

\section{Methods}

In the development of alternative management strategies for HPF sites and in the selection of the optimum one, the evaluation of the ecological, social and economic criteria together and the opinion of the interest groups (local community, public institution representatives, NGO representatives) will also increase the likelihood of making the right selection. There are many pure and hybrid Multi-Criteria DecisionMaking (MCDM) techniques that can be used for this purpose in the literature such as AHP (Analytic Hierarchy Process), ANP (Analytic Network Process), A'WOT (SWOTAHP), CJA (Conjoint Analysis), TOPSIS (Technique for Order of Preference by Similarity to Ideal Solution), TOPSIS-G (Technique for Order of Preference by Similarity to Ideal Solution with grey numbers), VIKOR (Multi-Criteria Optimization and Compromise Solution), ELECTRE (Elimination and Choice Expressing Reality), PROMETHEE (Preference Ranking Organization Method for Enrichment of Evaluations), SAW (Simple Additive Weighting), DEMATEL (Decision-Making Trial and Evaluation Laboratory) and DANP (DEMATEL-based ANP).

Considering the aim of the research, the most appropriate MCDM hybridization was decided to be A'WOT (SWOT-Analytic Hierarchy Process) and Conjoint Analysis (CJA) combination (A'WOT-CJA). Because within the scope of A'WOT-CJA, the honey status of Bartin Province was determined by SWOT and the obtained SWOT criteria were prioritized by digitizing by AHP. Thus, the factors standing out in each SWOT group formed the basis of HPF management strategies. Sub-levels should also be defined for the factors developed for more comprehensive strategies. In this way, the participants can better interpret and analyse the strategies. In this direction, a total of 81 strategies were developed by adding sub-levels to each SWOT factor. However, the strategies were reduced to 9 through orthogonal rotation in CJA, since it was difficult and time consuming to prioritise these 81 strategies. By this means, more consistent results were obtained. These 9 strategies were ranked by the 110 participants in the direction of CJA, and thus HPF optimum management strategy for Bartin Province was determined. The MCDM techniques used within the scope of the study are explained below. 


\section{A'WOT technique}

In the study, a hybrid technique A'WOT (SWOT Analysis and Analytical Hierarchy Process (AHP) combination) was used. A'WOT is a hybrid method developed by Kurttila et al. (2000) and Pesonen et al. (2001a). This method provides a structure combining the AHP method of Saaty (1980) with SWOT. The purpose of utilizing AHP in SWOT analysis is to evaluate the SWOT factors systematically. While SWOT analysis provides a frame for the decision status analysis, AHP supports more analytical application of SWOT (Kurttila et al., 2000; Kangas et al., 2001; Kajanus et al., 2004).

SWOT (Strengths, Weaknesses, Opportunities and Threats) is a commonly applied tool in the analysis of internal and external environment in order to provide a systematic approach and support to the cases of strategic decision making (Wheelen and Hunger, 1995, Hill and Westbrook, 1997). The purpose of SWOT implementation in the process of strategic planning is to develop and adopt a strategy that is generally adaptable between internal and external factors. SWOT can also be used, when alternative strategies emerge (McDonald, 1993). SWOT analysis is not capable of assessing the case of strategic decision making in a comprehensive way. It remains at the level of detecting the factors only. In addition to this, the expression of individual factors is often very general and short. Moreover, SWOT does not include tools for determining the significance of factors analytically or evaluating decision alternatives according to the factors. Therefore, the more use of SWOT is mainly based on the qualitative analysis carried out during the planning process and the skills and expertise of the people involved in the process. In summary, SWOT analysis is a list of internal and external factors or an incomplete qualitative examination. For this reason, it is sometimes called as "SoWOT" (Hill and Westbrook, 1997). General structure of SWOT Analysis realized within the scope of A'WOT is given in Table 2.

Table 2. Structure of SWOT analysis

\begin{tabular}{c|c|c}
\hline \multicolumn{2}{c}{ SWOT ANALYSIS } \\
\hline & POSITIVE FACTORS & NEGATIVE FACTORS \\
\hline $\begin{array}{c}\text { Internal } \\
\text { factors }\end{array}$ & $\begin{array}{c}\text { STRENGTH } \\
\text { (How can we utilize the Strength) }\end{array}$ & $\begin{array}{c}\text { WEAKNESS } \\
\text { How can we convert these to Strength }\end{array}$ \\
\hline $\begin{array}{c}\text { External } \\
\text { factors }\end{array}$ & $\begin{array}{c}\text { OPPORTUNITY } \\
\text { (How can we convert these to Strength) }\end{array}$ & $\begin{array}{c}\text { THRET } \\
\text { (How can we convert these to Opportunity) }\end{array}$ \\
\hline
\end{tabular}

When the operation strategy is required to be determined by using SWOT analysis only, the internal and external factors, which are effective on the strategy, are listed roughly, indefinitely and superficially and evaluated as qualitatively insufficient (Hill and Westbrook, 1997). That is to say, in the traditional SWOT analysis, effect of each factor on the proposed plan or strategy is not determined. This problem is overcome by using AHP. In the AHP, each factor is assigned relative priorities in the direction of binary comparisons (Masozera et al., 2006). Therefore, the missing aspects of the SWOT analysis in terms of measurement and evaluation are eliminated by AHP. Thus, SWOT groups and their factors become measurable and their priorities are quantified.

The idea of using AHP within the framework of a SWOT is to assess the SWOT factors systematically and to balance them according to their intensity (Saaty, 1980; 
Kurttila et al., 2000). When AHP is included in the SWOT analysis, it analyses the factors of SWOT analysis by comparing them with each other. AHP helps to conduct SWOT in a more analytical way and the AHP - SWOT combination is a hybrid model that is referred to as $\mathrm{A}^{\prime} \mathrm{WOT}$. The range of application of $\mathrm{A}^{\prime} \mathrm{WOT}$ technique is quite extensive and there are many studies available since it is mostly used in the field of forestry (Leskinen and Kangas, 1998, Kurttilla et al., 2000, Leskinen 2000, Pesonen et al., 2000, Pesonen et al., 2001b, Kajanus et al., 2004; Yilmaz, 2007; Leskinen et al., 2008; Gungor, 2011; Gungor and Sen, 2018). A'WOT decision hierarchy benefiting from the AHP is given in Figure 3.

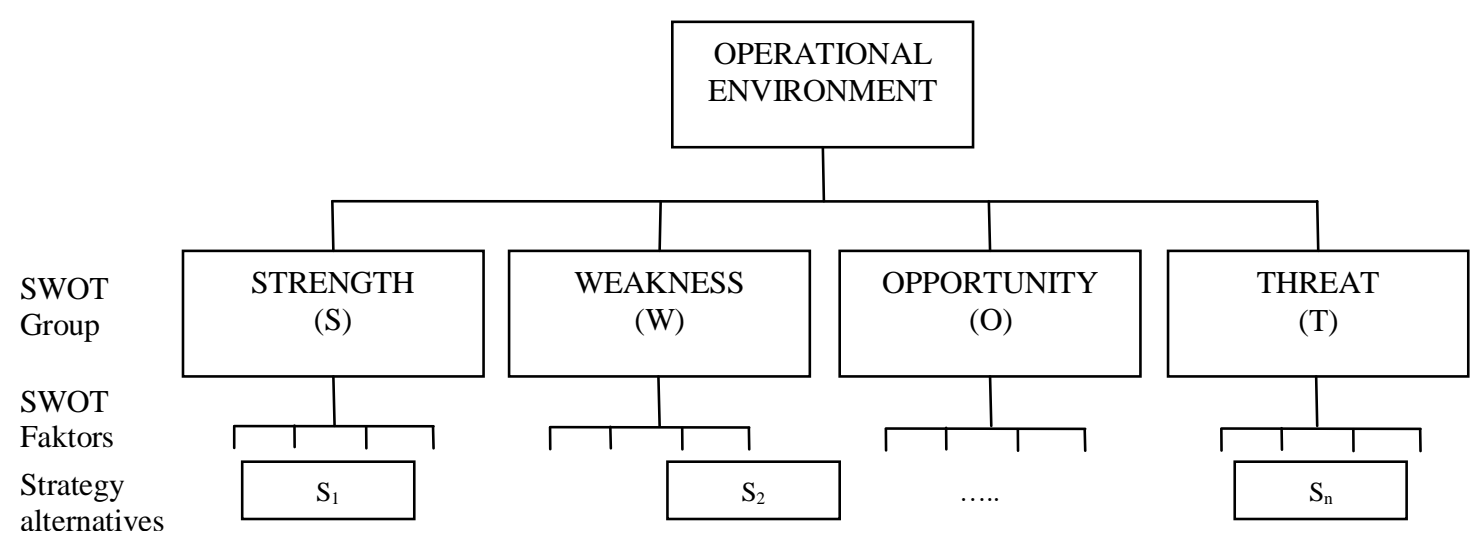

Figure 3. Hierarchical representation of A'WOT analysis (Kangas et al., 2001)

In the first step of the A'WOT technique, SWOT analyses are carried out. For this, firstly SWOT groups consisting of Strengths, Weaknesses, Opportunities and Threats are formed (Figure 3). Subsequently, the SWOT factors for each SWOT group are ranked as neutrally as possible. Thus, the internal and external equity factors obtained are included in the SWOT analysis. However, considering the fact that the human brain can compare up to $7 \pm 2$ elements at the same time (Schomoldt et al., 1995), the number of factors in each SWOT group should not be more than nine.

Later in the A'WOT technique, binary comparison operations are performed between the SWOT factors in each SWOT group. While these binary comparisons are being made, the one, who is performing the comparison is asked to state ordinance by asking questions such as "which factor is more preferred (important) when factor 1 is compared to factor 2?" and "how much more the factor, which is preferred more after that, is preferred than the other factor?" According to the information obtained from these comparisons, the relative significance (priorities) of the SWOT factors are calculated using the eigenvalue approach within the AHP technique. Then, the binary comparisons are made between the four SWOT groups. For this, a SWOT factor with the highest priority value is selected from each group to represent the group. Thus, by using these four SWOT factors selected from each group, the priority values of the SWOT groups are calculated using binary comparisons and eigenvalue approach, as in the previous step. In the next stage, the relative priority value of each SWOT group and the relative priority value of each of the SWOT factors in this group are multiplied separately. Thus, the overall priority value of each SWOT factor included in the relevant SWOT group is obtained. This operation is carried out separately for each of the four SWOT groups. As 
a result, the overall priority values of all SWOT factors, of which the total value is equal to one, are obtained (Kurttila et al., 2000; Pesonen et al., 2001a).

After making the comparisons in A'WOT, useful quantitative information about decision-making can be obtained (Kurttila et al., 2000). In addition, the use of A'WOT ensures the selection of alternatives according to each SWOT factor and each SWOT group (Pesonen et al., 2000). When the significance of different SWOT groups are identified, the selection alternatives can be prioritized as a whole in terms of strategic selection.

By including the AHP technique in SWOT analyses, SWOT groups and their factors become measurable and their priorities are set forth numerically. The weights of each calculated SWOT group and factors constitutes the basis of the strategies to be developed in the next step.

After the hierarchical structure model is created, matrices are created by making binary comparisons. Binary comparison is the comparison of two factors or criteria and is based on the judgment of the decision maker. By binary comparison, it is aimed to determine the relative significance of the elements in the hierarchy comparing to the element at the top level (Kurttila et al., 2000). In order to determine the significance levels of SWOT groups and factors among themselves in the AHS, $(n \times n)$ binary comparison matrices, which are shown in the formula given in equation 1 , are created (Saaty, 1995) and the criteria or alternatives are compared binarily.

$$
\mathrm{A}=\left[\begin{array}{ccccc}
1 & a_{21} & a_{31} & \cdots & a_{n 1} \\
1 / a_{21} & 1 & a_{32} & \cdots & a_{n 2} \\
1 / a_{31} & 1 / a_{32} & 1 & \cdots & a_{n 3} \\
\vdots & \vdots & \vdots & \ddots & \vdots \\
1 / a_{n 1} & 1 / a_{n 2} & 1 / a_{n 3} & \cdots & 1
\end{array}\right]_{n \times n}
$$

The relative significance of contribution to the purpose of each criteria given in Equation 1 and the superiority of each target are determined in a binary comparison of judgments (Saaty, 1980). The 1-9 significance scale developed by Saaty (1980) is used in order to assign value in the comparisons. The meanings expressed by the significance levels are shown in Table 3.

Table 3. Scale of relative significance (according to Saaty, 1980)

\begin{tabular}{c|c|c}
\hline $\begin{array}{c}\text { Intensity of } \\
\text { importance }\end{array}$ & Definition & Explanation \\
\hline 1 & $\begin{array}{c}\text { Equal importance } \\
\text { Weak importance of one over } \\
\text { another }\end{array}$ & $\begin{array}{c}\text { Two factors contribute equally to the objective. } \\
\text { Experience and judgement slightly favor one over the other. } \\
5\end{array}$ \\
$\begin{array}{c}\text { Essential or strong importance } \\
\text { Very strong or demonstrated } \\
\text { importance }\end{array}$ & $\begin{array}{c}\text { Experience and judgement strongly favor one over the another } \\
\text { Experience and judgement very strongly favor one over the other. } \\
9\end{array}$ & $\begin{array}{c}\text { Absolute importance } \\
\text { The evidence favoring one over the other is of the highest } \\
\text { possible validity }\end{array}$ \\
\hline
\end{tabular}


Following the formation of the binary comparison matrices the eigenvector of each item is calculated showing that an item is more important than the other items (Kurttila et al., 2000). The eigenvector of the matrix in dimension of $n \times 1$ is determined as follows (equation 2):

$$
i=1,2,3, \ldots, n \text { ve } j=1,2,3, \ldots, n
$$

$$
b_{i j}=\frac{a_{i j}}{\sum_{i=1}^{n} a_{i j}}
$$

In order to determine the significance distributions of the criteria, it is necessary to calculate the $\mathrm{W}=\left[\mathrm{w}_{\mathrm{i}}\right] \mathrm{nx} 1$ column vectors. W column vector is obtained from the arithmetic mean of the row elements of the matrix, which is the value of the $b_{y}$ values given in the formula given in Equation 2.

The consistency ratio (CR) for each of the binary comparison matrices is calculated (equation 3). For this ratio, an upper limit of 0.10 is required. The ratio being over 0.10 , means that there is inconsistency in decision making. In this case, improvement is necessary in judgement. The largest eigenvector of the matrix A ( $\lambda$ _max) is calculated and the CR value is obtained (equation 4).

$$
\begin{gathered}
i=1,2,3, \ldots, n \text { ve } j=1,2,3, \ldots, n \\
D=\left[a_{i j}\right]_{n x n} \times\left[W_{i}\right]_{n x 1}=\left[d_{i}\right]_{n x 1} \\
\lambda_{\max }=\frac{\sum_{i=1}^{n} \frac{d_{i}}{w_{i}}}{n}
\end{gathered}
$$

The randomness index (RI) is another value needed for calculating the consistency ratio. Table 4 contains the RI values which are determined from constant numbers and determined according to $\mathrm{n}$ value (Kurttila et al., 2000). The CR value is calculated according to the formula given in Equation 5.

$$
C R=\frac{\lambda-n}{(n-1) \cdot R I}
$$

Table 4. Randomness index

\begin{tabular}{ccccccccccc}
\hline $\mathrm{n}$ & 1 & 2 & 3 & 4 & 5 & 6 & 7 & 8 & 9 & 10 \\
$\mathrm{RI}$ & 0.00 & 0.00 & 0.58 & 0.90 & 1.12 & 1.24 & 1.32 & 1.41 & 1.45 & 1.49 \\
\hline
\end{tabular}

Later, the factors taking the highest values as a result of A'WOT calculations are detailed to make the strategies more effective. In this stage, Conjoint Analyses were utilized and more detailed strategies were developed in this way by adding criteria to the factors found in A'WOT results in the Conjoint Analysis. 


\section{Conjoint analysis}

The word Conjoint is a combination of the words CONside and JOINT. Conjoint Analysis (CJA) was developed in the 1970s (Orme, 2009). CJA is a market research method determining the consumer preferences of multi-featured goods or services that are effective in demand determination. By using this analysis, it is assumed that the value given to any product by a person corresponds to the total utility deriving from all of the determined qualities of that product and then, the likelihood of purchasing that product is in proportion to the benefit they obtain from that product. CJA determines the most customer satisfactory combination of the factors related to the product or service that they consider during the purchasing stage and at the same time ensures the determination of the most preferred factor levels for that product or service.

The measurement of tools is one of the most basic concepts in CJA which is designed as factors and sub-levels. A utility gives a subjective decision of preference of each participant. It also forms the conceptual basis for the measurement value which is a very important concept for this research (Anderson et al., 2010).

In case the number of factors and their levels are high in CJA, an extra burden will be added on the participants and the time speared for the research by participants will increase. Many participants may not want to participate in the survey since it will take too much time or even they do participate, they may give up they may quibble in order to save time (Louviere, 1988; Marshall and Bradlow, 2002). For this reason, there is no need to include a factor, which does not make any difference in the study to be carried out (Hair et. al, 1995). The number of factors to be used in CJA is usually between 4 and 7 and this number can increase up to 10 to 15 . The number of levels is determined to be between 2 and 5 (Scholl et. al, 2005).

A simple model of CJA, which is generally used to understand consumers' reactions or preferences to a product or service, is given in equation 6 (Malhotra, 1996; Raghavarao et. al, 2010):

$$
y_{k}=\sum_{j=1}^{J} \sum_{m=1}^{M_{i}} \beta_{j m} x_{j m}
$$

Here:

$\mathrm{y}_{\mathrm{k}} \quad$ : Total utility of an alternative,

$\beta_{\mathrm{jm}} \quad$ : Utility value of factor $\mathrm{j}$ at level $\mathrm{m}$,

$\mathrm{x}_{\mathrm{jm}} \quad$ : The dummy variable, which takes the value of 1 for level $\mathrm{m}$ of the factor $\mathrm{j}$ and 0 for the other cases, 1 if incentive $\mathrm{k}$ has value $\mathrm{m}$ of factor $\mathrm{j} 0$ else.

CJA, which includes statistical analysis such as correlation and regression and uses qualitative and quantitative data, analyses the effects of many independent variables by using the (utility) function as a dependent variable. In this way, the effect of each variable on consumer preference is determined.

CJA was used in many researches such as Irish consumer preferences for honey (Murphy et al., 2000), in the preference of local food producers (Darby et. al, 2008): in the preference stage of honey consumers in Czech Republic (Sanova et. al, 2017).

In this research, the strategies found as a result of A'WOT were ranked by CJA. For this, the significance of each factor and sub-level influencing the preferences were 
determined by CJA (utility, weight) and their combinations were presented to the participants. By this means, the optimum management strategy of HPF was determined.

\section{Preparation and implementation of survey forms}

SPSS (Statistical Package for Social Science) 21.0 package program was used for A'WOT and CJA. Surveys conducted under the context of A'WOT and CJA were implemented through face-to-face interviewing method in place. The surveys were made in the Central District, Amasra District and Kozcagiz District of Bartin.

The number of participants was determined according to the simple random sampling method. In this method, the sub-groups/layers are represented in the sample at the proportion of their weights in an environment of which the boundaries are set. In order to be able to make the sampling, the number of units to be selected from each subpopulation is determined by the share of that sub-population within the entire population (Kurant et al., 2011). Thus, the sample to be formed is guaranteed to represent the population with all its sub-units (Fuller, 2009). Participants in the study were assessed in three interest groups (in the sub-layer) as local residents, public institutions and NGOs in order to increase the precision of A'WOT and CJA analyses. Later, the number of participants, who were subject to the survey in each interest group, was calculated using the formula given in equation 7 (Daniel, 1999):

$$
n=\frac{N Z^{2} p q}{d^{2}(N-1) Z^{2} p q}
$$

Where:

$\mathrm{N}$ : Population size (102 people from the local population, 20 people from public institutions, and 98 people from NGOs),

$\mathrm{n}$ : Sample size (50 people from the local population, 10 people from public institutions, and 50 people from NGOs),

$\mathrm{Z}: \mathrm{Z}$ statistic for a level of confidence. Confidence level 95\% (1.96),

$\mathrm{p}$ : Probability of the presence of the aspect aimed to be measured within the main group (taken $50 \%$ due to the multi-purpose nature of this study),

q : $1-\mathrm{p}$,

d : Sampling error considered $10 \%(0.1)$.

As a result of the calculations made, surveys were made within the context of both A'WOT and CJA with a total of 110 people, 50 from local residents, 10 from public institutions and 50 from NGOs.

\section{Results and Discussion}

\section{SWOT findings and A'WOT calculations}

Evaluation of Bartin Province in terms of honey production is given in Table 5. SWOT outputs were evaluated by AHP under the scope of A'WOT and the values of SWOT groups and factors, which were considered to be effective in the development of HPF management strategies in Bartin, were obtained. 
Table 5. Consistency rates ${ }^{l}$ and priorities of SWOT groups and factors according to $A^{\prime} W O T$ results

\begin{tabular}{|c|c|c|c|c|c|}
\hline $\begin{array}{c}\text { SWOT } \\
\text { group }\end{array}$ & $\begin{array}{c}\text { Group } \\
\text { priority }\end{array}$ & $\begin{array}{l}\text { SWOT } \\
\text { factors }\end{array}$ & $\begin{array}{c}\text { Consist- } \\
\text { ratio }\end{array}$ & $\begin{array}{l}\text { Priority of } \\
\text { factor } \\
\text { within } \\
\text { group }\end{array}$ & $\begin{array}{c}\text { Overall } \\
\text { priority of } \\
\text { factor }\end{array}$ \\
\hline Strengths & 0.352 & $\begin{array}{l}\text { S1. Natural forests increasing the honey yield } \\
\text { S2. Old growth with organic honey production capability } \\
\text { S3. Nectar plants contributing in pollen quality } \\
\text { S4. Potential of producing chestnut, tilia, false locust and } \\
\text { rhododendron honey that are sold in high prices } \\
\text { S5. Proximity to major markets such as Istanbul and Ankara } \\
\text { S6. Scientists with experience in beekeeping } \\
\text { S8. Climatic and ecological structure that is suitable for } \\
\text { beekeeping }\end{array}$ & 0.104 & $\begin{array}{l}0.109 \\
0.171 \\
0.178 \\
\underline{\mathbf{0 . 2 4 5}} \\
0.094 \\
0.050 \\
0.032 \\
0.120\end{array}$ & $\begin{array}{l}0.038 \\
0.060 \\
0.063 \\
\underline{\mathbf{0 . 0 8 6}} \\
0.033 \\
0.018 \\
0.011 \\
0.042\end{array}$ \\
\hline Weaknesses & 0.172 & $\begin{array}{l}\text { W1. Honey yield below the average of Turkey, } \\
\text { W2. Low-yield stationary beekeeping activities instead of } \\
\text { high-yield migratory beekeeping, } \\
\text { W3. The understanding of seeing beekeeping as a hobby, } \\
\text { W4. Restricted capital transfers to beekeeping, } \\
\text { W5. Lack of information on food safety, } \\
\text { W6. Lack of registered beekeeper and uncontrolled } \\
\text { beekeeping, } \\
\text { W7. Inadequate and untended beekeeping education, } \\
\text { W8. High migration rate. }\end{array}$ & 0.101 & $\begin{array}{l}0.178 \\
\underline{\mathbf{0 . 2 0 2}} \\
0.170 \\
\underline{0.161} \\
0.080 \\
0.042 \\
0.103 \\
0.063\end{array}$ & $\begin{array}{l}0.031 \\
\underline{\mathbf{0 . 0 3 5}} \\
0.029 \\
0.028 \\
0.014 \\
0.007 \\
0.018 \\
0.011\end{array}$ \\
\hline Opportunities & 0.324 & $\begin{array}{l}\text { O1. High rate of increase in demand for apicultural products, } \\
\text { O2. The rural population capable of beekeeping, } \\
\text { O3. Flora's potential to produce high-yield apicultural } \\
\text { products (such as royal jelly, propolis, beeswax) } \\
\text { O4. Ever-growing market for organic products, } \\
\text { O5. National and international supports in financing } \\
\text { beekeeping, } \\
\text { O6. The key role of beekeeping in reducing migration, } \\
\text { O7. New international markets with export potential, } \\
\text { O8. Positive developments in OGM policies. }\end{array}$ & 0.109 & $\begin{array}{l}0.141 \\
0.039 \\
\underline{\mathbf{0 . 2 2 4}} \\
0.221 \\
0.060 \\
0.088 \\
0.153 \\
0.073\end{array}$ & $\begin{array}{l}0.046 \\
0.013 \\
\mathbf{0 . 0 7 3} \\
0.072 \\
0.019 \\
0.029 \\
0.050 \\
0.024\end{array}$ \\
\hline Threats & 0.151 & $\begin{array}{l}\text { T1. Social insecurity due to fake honey production, } \\
\text { T2. Bottlenecks in the marketing channels for the apicultural } \\
\text { products in Turkey, } \\
\text { T3. Lack of corporate company in honey production, } \\
\text { T4. Lack of understanding the importance of beekeeping in } \\
\text { rural development, } \\
\text { T5. In spite of favourable season for long-term honey } \\
\text { production, the short-term honey production season in } \\
\text { practice, } \\
\text { T6. Financial bottlenecks experienced in beekeeping, } \\
\text { T7. Shadow economy in honey production and sales, } \\
\text { T8. Lack of scientific knowledge on bee breeding and honey } \\
\text { production. }\end{array}$ & 0.079 & $\begin{array}{l}0.121 \\
0.112 \\
0.123 \\
0.118 \\
\underline{\mathbf{0 . 1 4 7}} \\
0.098 \\
0.110 \\
0.170\end{array}$ & $\begin{array}{l}0.018 \\
\text { 0.022 } \\
0.015 \\
0.017 \\
0.026\end{array}$ \\
\hline
\end{tabular}

\footnotetext{
${ }^{1}$ The consistency ratio of the comparisons between four SWOT groups was 0.093
} 
When Table 5 is examined, Strengths group has the highest score in the SWOT group with 0.352 . This is followed by Opportunities with 0.324 . Weaknesses with 0.172 ranks third and Threats with 0.151 is the last. According to these results, it is understood that in the development of the HPF management strategies for Bartin Province, a structure, which emphasizes Strengths and Opportunities and dismisses Weaknesses and Threats, should be adopted. Moreover, "S4" in the Strengths group has the highest score among the SWOT factors with 0.245 (0.086 in the total average). "O3" with 0.224 $(0,, 073$ in the total average) from Opportunities group ranks second. "W2" with 0.202 ( 0.035 in the total average) from the Weaknesses group ranks third and "T5" with 0.147 ( 0.022 in the total average) from the Threats group is the last one. In addition, showing the values obtained on the figure is given in Figure 4.

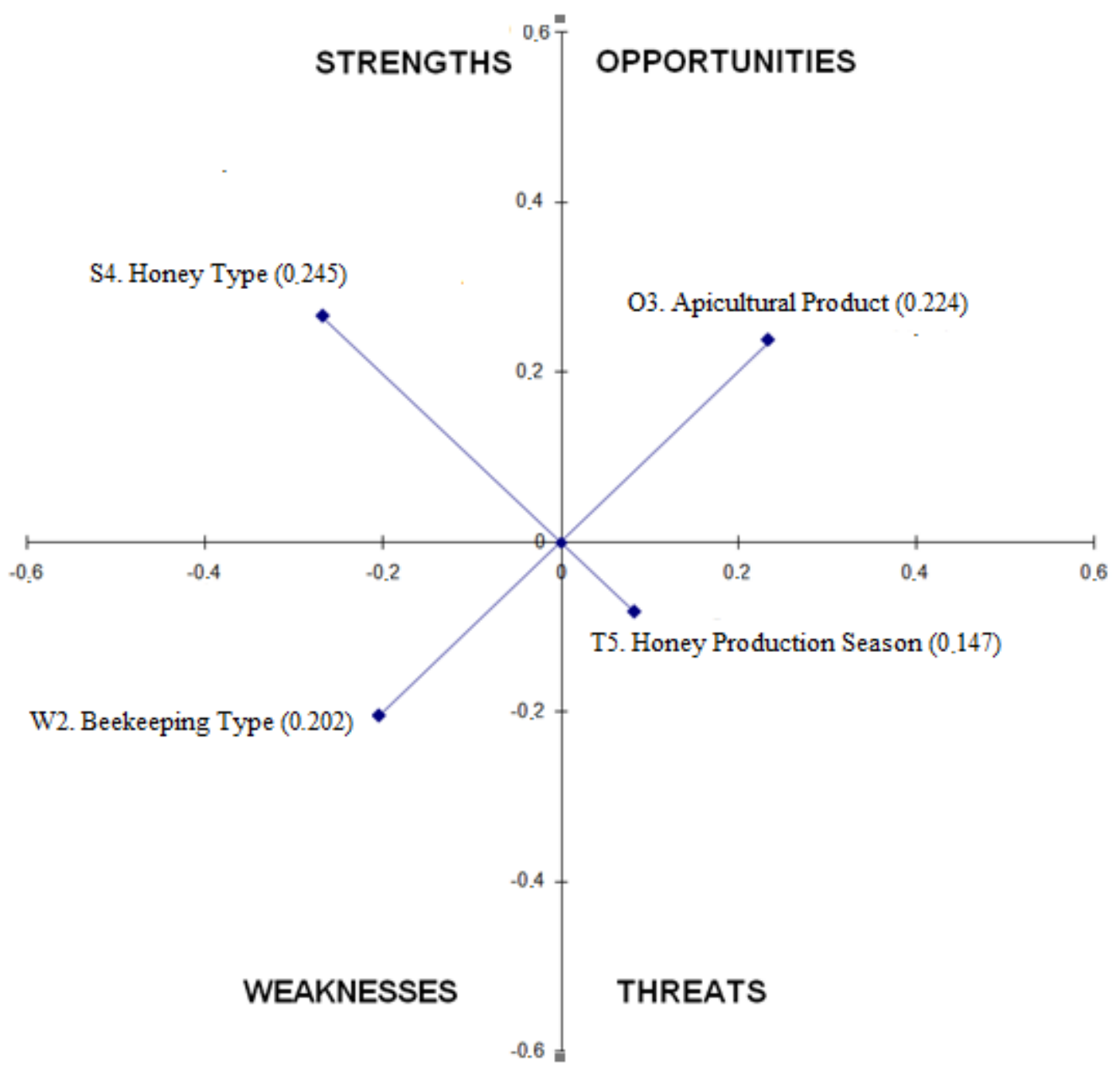

Figure 4. An illustration of the relative significance of SWOT factors in an A'WOT application to HPF optimum management strategy

\section{CJA calculations}

CJA was used in determining the sub-criteria of the factors determined by A'WOT. In the CJA calculations made according to the formula given in Equation 1, "preference score and order of priority for alternative HPF management strategies" was taken as the 
dependent variable. Dependent variable was measured by ordering and 9 strategies were used in ordering. In the development of the strategies, there were four independent factors (variables) determined by A'WOT and three levels developed under CJA (Table 6).

Table 6. A'WOT factors and CJA levels

\begin{tabular}{c|c|c|l}
\hline \multicolumn{2}{c|}{$\begin{array}{c}1^{\text {st }} \text { Step: Factors determined under } \\
\text { A'WOT }\end{array}$} & \multicolumn{1}{c}{$\mathbf{2}^{\text {nd }}$ Step: Levels developed under CJA } \\
\hline $\begin{array}{c}\text { SWOT } \\
\text { groups }\end{array}$ & $\begin{array}{l}\text { SWOT } \\
\text { factors }\end{array}$ & Factor Name & \multicolumn{1}{c}{ Factor Level } \\
\hline Strengths & S4 & Honey Type & $\begin{array}{l}\text { 1. Tilia + False Locust Honey } \\
\text { 2. Chestnut Honey } \\
\text { 3. Rhododendron Honey }\end{array}$ \\
\hline Weaknesses & W2 & Beekeeping Type & $\begin{array}{l}\text { 1. Stationary beekeeping on the same land } \\
\text { 2. Migratory beekeeping on the same land } \\
\text { 3. Migratory beekeeping on different lands }\end{array}$ \\
\hline Opportunities & O3 & Apicultural Product & $\begin{array}{l}\text { 1. Honey + Royal Jelly } \\
\text { 2. Propolis + Bee Venom } \\
\text { 3. Pollen + Beeswax }\end{array}$ \\
\hline Threats & T5 & $\begin{array}{l}\text { Honey Production } \\
\text { Season }\end{array}$ & $\begin{array}{l}\text { 1. Maximum 3 months } \\
\text { 2. Approximately 6 months } \\
\text { 3. 9 months and longer }\end{array}$ \\
\hline
\end{tabular}

By taking the factors and sub-levels in Table 4, it is possible to develop a total of $3^{4}=81$ combinations (strategies) on the basis of full design (full profile) (Green and Sirinavasan, 1978; Malhotra, 1996, Gungor, 2005). However, in this case it is difficult and time consuming for participants to prioritise 81 strategies. For this reason, management strategies have been developed in which each factor and sub-levels are independent (as an orthogonal design) (Hair et al., 1995; Smith, 1999). In the development of these strategies, in accordance with the CJA and for the purpose, the most negative level of each factor was taken as a reference (rhododendron honey for the factor of honey type, pollen+beeswax for apicultural product factor, maximum 3 months for honey production season, for the type of beekeeping stationary on the same land). For the remaining levels, 8 dummy variables with the values of 0 or 1 were defined. Based on this dummy variable defined, 9 alternative management strategies were developed based on orthogonal design (Table 7).

Table 7. HPF management strategies formed on the basis of orthogonal design in CJA

\begin{tabular}{|c|c|c|c|c|}
\hline \multirow[b]{2}{*}{$\begin{array}{l}\text { Strategy } \\
\text { No }\end{array}$} & \multicolumn{4}{|c|}{ Factors and Levels } \\
\hline & Honey Type & $\begin{array}{l}\text { Apicultural } \\
\text { Product }\end{array}$ & \begin{tabular}{|c|}
$\begin{array}{c}\text { Honey } \\
\text { Production } \\
\text { Season }\end{array}$ \\
\end{tabular} & Beekeeping Type \\
\hline 1 & Tilia + False Locust Honey & Pollen + Beeswax & $\begin{array}{c}\text { Approximately } \\
6 \text { months }\end{array}$ & $\begin{array}{c}\text { Stationary beekeeping on } \\
\text { the same land }\end{array}$ \\
\hline 2 & Tilia + False Locust Honey & $\begin{array}{c}\text { Propolis + Bee } \\
\text { Venom }\end{array}$ & $\begin{array}{c}\text { Maximum } 3 \\
\text { months }\end{array}$ & $\begin{array}{c}\text { Migratory beekeeping on } \\
\text { the same land }\end{array}$ \\
\hline 3 & Chestnut Honey & $\begin{array}{l}\text { Honey + Royal } \\
\text { Jelly }\end{array}$ & $\begin{array}{c}\text { Approximately } \\
6 \text { months }\end{array}$ & $\begin{array}{c}\text { Migratory beekeeping on } \\
\text { the same land }\end{array}$ \\
\hline 4 & Tilia + False Locust Honey & $\begin{array}{c}\text { Honey + Royal } \\
\text { Jelly }\end{array}$ & $\begin{array}{l}9 \text { months and } \\
\text { longer }\end{array}$ & $\begin{array}{c}\text { Migratory beekeeping on } \\
\text { different lands }\end{array}$ \\
\hline
\end{tabular}




\begin{tabular}{|c|c|c|c|c|}
\hline 5 & Rhododendron Honey & Pollen + Beeswax & $\begin{array}{l}9 \text { months and } \\
\text { longer }\end{array}$ & $\begin{array}{l}\text { Migratory beekeeping on } \\
\text { the same land }\end{array}$ \\
\hline 6 & Rhododendron Honey & $\begin{array}{l}\text { Propolis + Bee } \\
\text { Venom }\end{array}$ & $\begin{array}{l}\text { Approximately } \\
6 \text { months }\end{array}$ & $\begin{array}{l}\text { Migratory beekeeping on } \\
\text { different lands }\end{array}$ \\
\hline 7 & Chestnut Honey & $\begin{array}{c}\text { Propolis + Bee } \\
\text { Venom }\end{array}$ & $\begin{array}{c}9 \text { months and } \\
\text { longer }\end{array}$ & $\begin{array}{c}\text { Stationary beekeeping on } \\
\text { the same land }\end{array}$ \\
\hline 8 & Chestnut Honey & Pollen + Beeswax & $\begin{array}{l}\text { Maximum } 3 \\
\text { months }\end{array}$ & $\begin{array}{l}\text { Migratory beekeeping on } \\
\text { different lands }\end{array}$ \\
\hline 9 & Rhododendron Honey & $\begin{array}{c}\text { Honey + Royal } \\
\text { Jelly }\end{array}$ & $\begin{array}{l}\text { Maximum } 3 \\
\text { months }\end{array}$ & $\begin{array}{c}\text { Stationary beekeeping on } \\
\text { the same land }\end{array}$ \\
\hline
\end{tabular}

Later on, special cards were prepared for the strategies in Table 7 and presented through personal interviews. The interviews were held in Bartin in 2016 with representatives of local residents and state institutions and non-governmental organizations. The number of persons interviewed was found using the formula (Equation 7) that gives sample size in limited communities.

\section{Determination of optimum management strategy}

As required by CJA, the participants were asked to rank the strategies, which are formed according to Table 7, from the best to the worst. The optimum management strategy for the HPF in Bartin was determined as the result of the analysis of the linear regression model, in which the average of the priorities given by 110 participant to each strategy is considered the dependent variable and the dummy variable levels of the factors as independent variable, using CJA.

According to the CJA results, in the strategies developed during the establishment process of honey forest, "Honey Production Season "with 34.44\% ranks first, "Beekeeping Type" with $28.15 \%$ ranks second, "Honey Season" with $22.66 \%$ ranks third and "Apicultural Product" factor with $14.75 \%$ ranks last (Table 8).

Table 8. CJA results

\begin{tabular}{|c|c|c|c|}
\hline Factor Name & Factor Levels & $\begin{array}{c}\text { Utility } \\
\text { Coefficient }\end{array}$ & $\begin{array}{c}\text { Significance } \\
\text { Level }(\%)\end{array}$ \\
\hline \multirow{3}{*}{ 1. Honey Type } & 1.1. Tilia + False Locust Honey & -0.151 & \multirow{3}{*}{22.66} \\
\hline & 1.2. Chestnut Honey & 0.572 & \\
\hline & 1.3. Rhododendron Honey & -0.421 & \\
\hline \multirow{3}{*}{ 2. Apicultural Product } & 2.1. Honey + Royal Jelly & 0.507 & \multirow{3}{*}{14.75} \\
\hline & 2.2. Propolis + Bee Venom & -0.363 & \\
\hline & 2.3. Pollen + Beeswax & -0.144 & \\
\hline \multirow[b]{2}{*}{ 3. Honey Production Season } & 3.1. Maximum 3 months & -0.748 & \multirow[b]{2}{*}{34.44} \\
\hline & $\begin{array}{l}\text { 3.2. Approximately } 6 \text { months } \\
\text { 3.3. } 9 \text { months and longer }\end{array}$ & $\begin{array}{l}0.421 \\
0.327\end{array}$ & \\
\hline 4. Beekeeping Type & $\begin{array}{l}\text { 4.1. Stationary beekeeping on the same land } \\
\text { 4.2. Migratory beekeeping on the same land } \\
\text { 4.3. Migratory beekeeping on different lands }\end{array}$ & $\begin{array}{r}-0.993 \\
0.565 \\
0.428\end{array}$ & 28.15 \\
\hline
\end{tabular}


For the most preferred and most important "Honey Production Season" factor, the "Honey production season being approximately 6 months" level with a utility coefficient of 0.421 ranked first, the "Honey production season being 9 months and longer" level with the utility coefficient of 0.327 ranked second, the "Honey production season being maximum of 3 month" level with the utility coefficient of -0.748 ranked third.

According to these results, participants want the honey production season to be approximately 6 months. Bartin Province $(770 \mathrm{~mm})$, which in fact has a rainfall average above the Turkey's rainfall average $(573 \mathrm{~mm}),($ BMST, 2017) is also above the country average $(17 \%)$ in terms of honey plant rate (the average of Bartin Province is $23 \%$ ) (GDF, 2011). This situation provides an advantage to Bartin Province in terms of honey production. However, when the yield level statistics per hive are examined (Table 1), it is understood that the hive yield is below the country average.

The honey production season shorter than three months means a low income for the beekeeper and it causes them to spend the rest of the year actively and makes it necessary for them to deal with other works. This prevents the desired specialization in beekeeping and causes people to consider beekeeping as a hobby (Korkmaz at all, 2015). It is possible to find the same result in other countries as well. For example, according to data of 2010, around $76 \%$ of beekeepers in Europe see this work as a hobby. However, around 10\% does beekeeping professionally. However, in Kosovo and Hungary, $20 \%$ or less of the beekeepers were hobbyists. In Romania, about half of all beekeepers were hobbyists. Except for Kosovo, Greece, Romania and Spain, professional beekeepers represented less than $10 \%$ of the total population of beekeepers (Chauzat et al., 2013).

Although the beekeepers react positively to the fact that the honey production season is 9 months or longer, the latter statements indicates that this will not be possible in Bartin and its surrounding regions. Likewise, experienced beekeepers and institutional officials stated that honey yield has decreased after the extension of season (6 months and more), especially in the production of chestnut honey (Gungor and Ayhan, 2016).

For the "Beekeeping Type" factor, which has the second important place in the strategy, the "Migratory beekeeping on the same land" level is the most preferred one with a utility coefficient of 0.565 . This was followed by "Migratory beekeeping on different lands" with a coefficient of 0.428. The least preferred is the "Stationary beekeeping on the same land" with the coefficient of -0.993. According to these results, it is understood that the participants are more interested in migratory beekeeping than stationary beekeeping. When the literature related to the subject is examined (GDF, 2011, 2012a, 2012b; BAKKA, 2011; BHFP, 2013; HFAP, 2013; Gungor and Ayhan, 2016; Gungor and Sen, 2018) it is understood that for the success of beekeeping, it is a must to shift from stationary beekeeping to migratory beekeeping.

The point to be considered here is the performance of "migratory beekeeping on the same land" activity instead of "migratory beekeeping on different lands", which is a more comprehensive beekeeping activity, due to limited capital and labour in shifting from stationary beekeeping to migratory beekeeping. Likewise, when considering the rough structure of the Bartin Province and its surrounding topography (BHFP, 2013), and the honey plant richness (Genc, 2003; Misir, 2011), different vegetation periods can be observed even in the case of a single honey forest in the same year. For this reason, a certain amount of accumulated capital and labour should be ensured in beekeeping first 
and in the next stage, migratory beekeeping, which is the way of professional beekeeping that should be adopted.

For the "Honey Type" factor, which has the third important place, the level of "Chestnut Honey" is the most preferred one with a utility coefficient of 0.572 , while the other levels are less preferred. When looking at the market sales prices of the region for honey, it is understood that the highest return belongs to chestnut honey (BAKKA, 2011; FAO, 2009, 2018; Gungor and Ayhan, 2016; TUIK, 2017; BAB, 2017; Gungor and Sen, 2018). This, naturally draws the attention of the beekeepers and the community to chestnut honey. Just like the honeydew honey in Mugla and Anzer honey in Rize, the chestnut honey draws the attention of honey consumers and producers in Bartin. The obtained results of the survey are also corroborative regarding the interest in chestnut honey in Bartin. The interest for the chestnut honey in Bartin Province was also observed in another province of Turkey. In other words, it was determined that the consumers from Izmir knew the chestnut honey with 33.3\%, citrus honey with $9.4 \%$, thyme honey with $21.6 \%$, hayit honey with $11.8 \%$ and French Lavender honey with $3.9 \%$ (Baki et al., 2017). However, due to climatic conditions, the production values of chestnut honey in the region change from year to year (TUIK, 2017). Likewise, the average rainfall of the last 5 years $(690 \mathrm{~mm})$ is lower than the average of the last 50 years $(770 \mathrm{~mm})($ BMST, 2017). For this reason, during the last 5 years, there have been significant decreases in the production of chestnut honey in Bartin Province (TUIK, 2017) and many beekeepers have suffered from this (BAB, 2017). In order to avoid experiencing this suffering, beekeepers need to enrich the honey variety taking into account the climatic conditions and to take preventive and protective measures against fluctuations in honey prices such as the diversity of the portfolio in the economy. Based on what has been told, it will be appropriate to take other types of honey (linden honey, false locust honey and rhododendron honey) into consideration in addition to chestnut honey.

For the "Apicultural Product" factor, which ranks the last meaning the least important one, the "Honey + Royal Jelly" level was the most preferred one and the "Propolis + Bee Venom" level was least preferred one with a utility coefficient of 0.507. The obtained results show that level of interest and knowledge of beekeepers and people of the region on apicultural products is inadequate.

In another study conducted in this subject (Baki et al., 2017), it was understood that $60 \%$ of the consumers consumed pollen, $36 \%$ consumed propolis and $4 \%$ consumed the royal jelly. However, it was determined that they did not use cream containing bee venom for therapeutic purposes. While the consumption of cream honey, organic honey and royal jelly was not encountered in studies conducted in previous years (Saner et al., 2011), in this study the consumer, who consumed these products, were encountered despite the low rate and number. Based on the formation of required consumer awareness, increased consumption of such apicultural products depends on ensuring healthy production and accessibility to these products in Turkey (Baki et al., 2017).

When it comes to beekeeping, the most common product coming to mind is honey. In fact, since honey is the most profitable product among the apicultural products, the result of this survey can be considered as natural. However, both for the sustainability of production and in order to increase the income generated from apicultural products and to reduce the risks, other apicultural products such as propolis and royal jelly should also be produced and consumed in the region (Baki et al., 2017). 
In order to ensure diversity in apicultural products, some progress has to be made in beekeeping as well. For example, the approach of regarding beekeeping as a second occupation or even as a hobby should be put up, specialized and qualified beekeeping activities should be performed and the capital allocated by the beekeepers for this work in this context should be increased (Park ve Youn, 2012). In addition, it is a must to have extensive knowledge on beekeeping in order to obtain all of the apicultural products. In a study conducted in Japan and South Korea (Kohsaka et al., 2017) on this subject, it was emphasized that the combination of traditional methods of beekeeping with modern methods would be important for beekeepers.

When the honey yield values of the World, Turkey and Bartin Province are compared, the average annual honey yield of our country $(15 \mathrm{~kg})$ is considerably lower than the world average $(22 \mathrm{~kg})$ (FAO, 2018). Bartin's honey yield value (14 kg), which is already below the world average, is also lower than the country's average (TUIK, 2017). Hive presence of Bartin and Turkey, which is in good state when compared in terms of the hive presence of the world, does not comply with the values obtained in honey production and honey yield (Gungor and Ayhan, 2016). In a comparison made for European countries, it was reported that honey yield levels and hive numbers of EU countries are also below the world average (Chauzat et al., 2013).

On the other hand, it should also be known that the increase in crop yields of plants provided by bees through pollination is 10-12 times (Yakovleva, 1975), even 20 times (Crane, 1972; 1975) of the monetary value gained from apicultural products. Also, there are many studies regarding the benefits of bees on pollination (EFSA, 2013; Goulson, 2013; IUCN, 2013, etc.). When including the economic values to be obtained indirectly through positive externalities in the light of this information, the honey production quantities and economic return of the HPF in Bartin Province will rise to higher levels.

\section{Conclusions}

In the research, a structure, which takes the ecological, social and economic values into consideration and acts according to the participation principle, was taken into consideration and A'WOT-CJA calculations were made within this scope. In the establishment phase of HPF, the current situation is set forth by SWOT analysis, prioritized with AHP (according to A'WOT technique) and arranged by CJA. For this reason, the research is the first forestry study in Turkey where A'WOT-CJA are used together.

According to the A'WOT findings obtained, Strengths (0.352) ranks first, Opportunities (0.324) ranks second, Weaknesses (0.172) ranks third, and Threats (0.151) ranks fourth in SWOT groups. In the development of management strategies in the direction of A'WOT, a structure, which emphasizes Strengths and Opportunities and dismisses Weaknesses and Threats, was adopted. According to this, the presence of natural forests and honey plants increasing the honey yield in A'WOT, the fact that the chestnut honey, which has a high market price and is in demand, is produced in the region, the long honey season and the existence of production potential of apicultural products such as pollen, beeswax and propolis including honey are the factors standing out.

In the research, sub-levels were added to the factors found in the A'WOT result (honey type, apicultural product, honey production season, beekeeping type) in CJA and optimum management strategy was determined to be "In the province of Bartin, 
chestnut type with high yield of honey should be given priority, the lands, where the flora is rich in terms of honey plants, should be selected as honey forest areas, these lands should be prepared especially in the way of increasing honey and royal jelly yield, the lands, where the honey production lasts approximately six months, should be highlighted in land selection and the honey forest lands should be constructed in a way to support migratory beekeeping." as a result of CJA calculations.

A'WOT-CJ model used under the scope of the research can be used in the prioritization stage of HPF lands, which are planned to be set up in Turkey, and in the decision making stage. By using A'WOT-CJA, which has an analytical structure, including the HPF management plans will have a more dynamic structure and potential conflicts between beneficiaries, local residents and management can be avoided as the opinions of the interest groups, meaning participants, were taken into consideration at the planning stage. Besides, the HPFs to be established in line with the developed strategy will contribute to the formation of a sustainable structure, to local beekeeping and to rural development. The HPFs, which have an important position in terms of food security, should be one of the priority issues in the strategies to be developed in order to support the rural population in Turkey.

In the study, a hybrid MCDM method was applied in determining the HPF management strategies. In this method, A'WOT and CJA techniques are used together. From this aspect, it is possible to state that it is a case study in the field of prioritizing natural sciences, forestry and management strategies. In addition, A'WOT-CJA followed in this study will be a role model for future research projects.

Acknowledgments. This research did not receive any specific grant from funding agencies in the public, commercial, or not-for-profit sectors.

\section{REFERENCES}

[1] Anderson, R. E., Babin, B. J., Black, W. C., Hair, J. F. Jr. (2010): Multivariate Data Analysis: A Global Perspective. - Pearson Education, New York.

[2] BAB, (2017): Bartin Aricilar Birligi Uretici Verileri. - Bartin Beekeepers Association. http://www.bab.org.tr/veriur, Retrieved:15.02.2017.

[3] Baki, F., Saner, G., Adanacioglu, H., Guler, D. (2017): Turkiye'de Suzme Cam Balina Yonelik Tuketici Tercihlerinin Konjoint Analizi: Izmir Ili Ornegi. - Balkan and Near Eastern Journal of Social Sciences 3(2): 50-57.

[4] BAKKA (2011): Bölgesel Göstergeler TR81 Zonguldak-Karabük-Bartın.-Batı Karadeniz Kalkinma Ajansi Yayinlari, Zonguldak.http://www.tuik.gov.tr/Kitap.do?metod=KitapDetay\&KT_ID=0\&KITAP_ID=185, Access:18.10.2017.

[5] Bekar, M., Acar, C. (2017): Bal Ormanları Icin Onemli Olan Bitkilerin Trabzon Bolgesinde Incelenmesi. - Akademik Sosyal Arastirmalar Dergisi 5(48): 435-444.

[6] BG (2017): Bartin Governorship. http://www.bartin.gov.tr/merkzilce. 01.05.2017.

[7] BHFP (2013): Bartin Honey Production Forest Project. - Orman ve Su Bakanligi, Bartin Orman Isletme Mudurlugu Yayinlari, Bartin.

[8] BMST (2017): Bartin Meteorology Station Data. - http://www.mgm.gov.tr/tahmin/il-veilceler.aspx?m=BARTíN. Access:18.02.2017.

[9] Carsjens, G. J., Vanderknaap, W. (2002): Strategic Land-Use Allocation: Dealing with Spatial Relationships and Fragmentation of Agriculture. - Landscape and Urban Planning 58(2-4): 171-179. 
[10] Chauzat M-P, Cauquil L, Roy L, Franco S, Hendrikx P, et al. (2013): Demographics of the European Apicultural Industry. - PLoS ONE 8(11): e79018. doi:10.1371/journal.pone.0079018.

[11] Clutter, J. L., Fortson J. C., Pienaar L. V., Brister G. H. ve Bailey R. L. (1992): Timber Management. - Krieger Publishing Company, Florida, USA.

[12] Crane, E. (1972): Bees in the pollination of seed crops. - J. Royal Agri.Soc., England.

[13] Crane, E. (1975): Honey a Comprehensive Survey. - Heinemann, London, England.

[14] Daniel, W.W. (1999): Biostatistics: A Foundation for Analysis in the Health Sciences (7th edition). - New York: John Wiley \& Sons.

[15] Darby K, Batte MT, Ernst S, Roe B. (2008): Decomposing local: a conjoint analysis of locally produced foods. - American Journal of Agricultural Economics 90: 476-486. DOI: $10.1111 / \mathrm{j} .1467-8276.2007 .01111 . x$

[16] Dogaroglu, M. (2017): Modern Aricilik Teknikleri. - Anadolu Matbaası, Istanbul.

[17] Duerr, W. A. (1993): Introduction to Forest Resource Economics. - McGraw-Hill, Inc. USA.

[18] Eastman, J. R., Jiang, H., Toledano, J. (1998): Multi-Criteria and Multi-Objective Decision Making for Land Allocation Using GIS. Multicriteria Analysis for Land-Use Management. - In: Beinat E., Nijkamp P. (eds.) Multicriteria Analysis for Land-Use Management. Environment \& Management, vol 9. Springer, Dordrecht

[19] EFSA (European Food Safety Authority) (2013): Pesticides and bees: EFSA finalises new guidance (Guidance on the risk assessment of plant protection products on bees (Apis mellifera, Bombus spp. and solitary bees)). - EFSA Journal 11(7): 3295. DOI:10.2903/j.efsa.2013.3295

[20] FAO (2009): Bees and their role in forest livelihoods. - www.fao.org/3/a-i0842e.pdf. Access: 17.01.2017.

[21] FAO (2013): Food and Agr. Org. Honey Inf. - http://www.fao.org. Access:22.04.2017.

[22] FAO (2018): Food and Agr. Org. Honey Inf. - http://www.fao.org. Access:17.02.2018.

[23] FODB (2005): Zonguldak Orman Bolge Mudurlugu, Bartin Orman İsletme Mudurlugu Amenajman Planı (2006-2025), II. Yenileme. - (Tum Seflikler), Bartin.

[24] Fuller, W. A. (2009): Sampling Statistics. - Wiley Series in Survey Methodology, SBN13: 978-0470454602, ISBN-10: 0470454601, USA.

[25] GDF (2011): Turkiye Onemli Ballı Bitkilerin Polen ve Nektar Potansiyelleri ile Yayılım Alanlar1, Ankara. $\quad-\quad$ https://www.ogm.gov.tr/ekutuphane/Dokumanlar.pdf. Access:09.01.2017.

[26] GDF (2012a): Arhavi Bal Ormani Projesi. - http://balormani.ogm.gov.tr. Access:09.01.2017.

[27] GDF (2012b): Bayat Bal Ormani Projesi. - http://balormani.ogm.gov.tr. Access: 09.01.2017.

[28] GDF (2014): Turkiye Ormanlari. - http://www.ogm.gov.tr/Sayfalar/Ormanlarimiz/IllereGore-Orman-Varligi.aspx. Access: 20.01.2015.

[29] GDF (2015): Turkiye Orman Varligi. - https://www.ogm.gov.tr/ekutuphane/Yayinlar. Access: 15.02.2017.

[30] Genc, Y. (2003): Iskalan Bolgesi (Bartin) Ballarinda Polen Analizi. - Undergraduate Thesis (Unpublished) ZKU, Fen Bilimleri Enstitusu, Bartin.

[31] Green, P. E., Srinivasan, V. (1978): Conjoint Analysis in Consumer Research: Issues and Outlook. - Journal of Consumer Research 5(2): 103-123.

[32] Goulson, D. (2013): An overview on the environmental risks posed by neonicotinoid insecticides. - Journal of Applied Ecology 50(4): 977-987.

[33] Gungor, E. (2005): Kastamonu-Bartin Kure Daglari Milli Parki’nin Optimum Yonetim Stratejisinin Gelistirilmesi. - ZKU, Fen Bilimleri Enstitusu, Bartin.

[34] Gungor, E. (2011): Orman Kaynaklarinin Butunlesik Islevsel Yonetim Planlamas1. Bartin Universitesi Fen Bilimleri Enstitusu, Yayımlanmamıs Doktora Tezi, Bartin. 
[35] Gungor, E., Ayhan, A. B. (2016): Bartin Yoresi Orman Kaynaklarının Bal Uretim Potansiyeli ve Ekonomik Degeri. - SDU, Turkish Journal of Forestry 17(1): 108-116.

[36] Gungor, E., Sen, G. (2018): Selecting suitable forest areas for honey production using the ahp: a case study in Turkey. - CERNE 24(1): 67-79.

[37] Hair, J. F., Anderson, R. E., Tatham, R. L., Block, W. C. (1995): Multivariate Data Analysis with Readings. - McMillan Book Company, London.

[38] HFAP (2013): Honey Production Forest Action Plan. - Orman ve Su Bakanlıg1, OGM Yayinlar1, Ankara. https://www.ogm.gov.tr/ekutuphane/Yayinlar/ Bal\%20Orman\%C4\%B1\%20Eylem\%20Plan\%C4\%B1\%20\%282013-17\%29.pdf., Retrieved:10.06.2017.

[39] Hill, T. Westbrook, R. (1997): SWOT Analysis: It's Time for a Product Recall. - Long Range Planning 30(1): 46-52.

[40] IUCN (International Union for Conservation of Nature) (2013): The IUCN Red List of Threatened Species (Europe), International Union for Conservation of Nature (IUCN), [Online]. - Available: www.iucnredlist.org/initiatives/europe. Access: July 2017.

[41] Kajanus, M. Kangas, J., Kurtilla, M. (2004): The Use of Value Focused Thinking And The A'WOT Hybrid Method In Tourism Management. - Tourism Management 25(4): 499-506.

[42] Kangas, J., Pesonen, M., Kurttila, M., Kajanus, M. (2001): A'WOT: Integratıng the AHP with SWOT Analysis, ISAHP 2001. - Berne, Switzerland.

[43] Klempeer, W. D. (1996): Forest Resource Economics and Finance. - McGraw-Hill International Editions, Forestry Series, ISBN 0-07-035122-8, USA.

[44] Kohsaka, R., Park, M. S., Uchiyama, Y. (2017): Beekeeping and honey production in Japan and South Korea: past and present. - Journal of Ethnic Foods 4(2): 72-77.

[45] Korkmaz, M., Avc1, M., Ozdemir, I. (2015): Kızılcam Ormanlarında Cam Balı Uretimine Yonelik Sorunlar ve Cozum Onerileri. - IV. Ormancilikta Sosyo-Ekonomik Sorunlar Kongresi, 15-17 Ekim 2015, Trabzon: 202-213.

[46] Kurant, M., Gjoka, M., Butts, C. T., Markopoulou, A. (2011): Walking on a graph with a magnifying glass: stratified sampling via weighted random walks. - SIGMETRICS '11 ACM SIGMETRICS International Conference on Measurement and Modeling of Computer Systems (Co-located with FCRC 2011) San Jose, CA, USA - June 07-11, 2011: 281-292.

[47] Kurttila, M., Pesonen, M., Kangas, J. and Kajanus, M. (2000): Utilizing The Analytical Hierarchy Process (AHP) in SWOT Analysis - A hybrid method and its application to a forest-certification case. - Forest Policy and Economics 1: 41-52.

[48] Leskinen, P., Kangas, J. (1998): Analysing uncertainties of interval judgment data in multiple-criteria evaluation of forest plans. - Silva Fennica 32: 363-372.

[49] Leskinen P. (2000): Measurement scales and scale independence in the Analytic Hierarchy Process. - Journal of Multi-Criteria Decision Analysis 9: 163-174.

[50] Leskinen, P., Kurttila, J., Kangas, M., Kajanus, M. (2008): Adopting Modern Strategic Decision Support Tools In The Participatory Strategy Process - A Case Study of a Forest Research Station. - Forest Policy And Economics 8: 267-278.

[51] Leuschner, W. A. (1992): Introduction to Forest Resource Management. - Krieger Publishing Company, Malabar, Florida.

[52] Louviere J. J. (1988): Analyzing Decision Making: Metric Conjoint Aanalysis. - Sage University Papers Series on Quantitative Applications in the Social Sciences, series No. 07-067. Sage Publications, Newbury Park.

[53] Malhotra, N. (1996): Marketing Research: An Applied Orientation. - Prentice-Hall, Inc., USA.

[54] Marshall P, Bradlow E. T. (2002): A unified approach to conjoint analysis models. Journal of the American Statistical Association 97: 674-682. DOI: 10.1198/016214502388618410. 
[55] Martell, D. L., Gunn, E. A., Weintraub, A. (1998): Forest Management Challenges for Operational Researches. - European Journal of Operational Researches 104(1): 1-17.

[56] Masozera, M. K., Alavalapat1, J. R. R., Jacobson, S. K., Shrestha, R. K. (2006): Assessing the Suitability of Community-Based Management for the Nyungwe Forest Reserve, Ruanda. - Forest Policy and Economics 8: 206-216.

[57] McDonald, M. H. B. (1993): The Marketing Planner. - Butterworth-Heinemann, Oxford.

[58] Misır, M. (2011): Arıt Bolgesi (Bartin) Ballarında Polen Analizi. - Yuksek Lisans Tezi (Yayımlanmamıs), ZKU, Fen Bilimleri Enstitusu, Bartin.

[59] Murphy, M., Cowan, C., Henchion, M., O’Reilly, S. (2000): Irish consumer preferences for honey: a conjoint approach. - British Food Journal 102: 585-598. DOİ: $10.1108 / 00070700010348424$.

[60] OCEP (2013): Beekeeping. - Ordu Commodity Exchange Publications. (Aricilik. Ordu Ticaret Borsas1 Yayinları). http://www.ordutb.org.tr/admin/dosya/aricilik_son(_201 3)(1).pdf. Access: 15.10.2015.

[61] Orme, B. (2009): "Which Conjoint Method Should I Use". - Sawtooth Software, Copyright Sawtooth Software, (http://www.sawtoothsoftware.com). Access: 16.02.2018.

[62] Park, M. S., Youn, Y. C. (2012): Traditional knowledge of Korean native beekeeping and sustainable forest management. - Forest Policy Econ. 15: 37-45.

[63] Pesonen, M., Ahola, J., Kurttila, M., Kajanus, M., Kangas, J. (2000): Investment strategies of Finnish forest industry in North America: A case study using A'WOT. - In: Munn, I., Bullard, S. H., Grado, S. C. \& Grebner, D. L. (eds.) SOFEW '99. Southern Forest Economics Workshop. April 18-20. Biloxi, MS. Proceedings of the 1999: 43-49.

[64] Pesonen, M., Kangas, J., Kurttila, M., Kajanus, M. (2001a): Applying A'WOT to choose a management strategy for the forest holding owned by private partnership. - In: Väyrynen, J. \& Niskanen, A. (eds.) International Symposium on Economic Sustainability of Small-scale Forestry. IUFRO Working Unit 3.08.00: Small-scale Forestry. 20-26 March, 2001, Joensuu, Finland. Abstracts.

[65] Pesonen, M., Kurtt1la, M., Kangas, J., Kajanus, M. And Heinonen, P. (2001b): Assessing the Priorities Using A'WOT among Resource Management Strategies at the Finnish Forest and Park Service. - Forest Science 47(4): 534-541.

[66] Raghavarao, D., Wiley J. B., Chitturi P. (2010): Choice-Based Conjoint Analysis: Models and Designs. - CRC Press, Boca Raton, USA.

[67] Saaty, T. L. (1980): The Analytic Hierarchy Process. - McGraw-Hill, New York.

[68] Saaty, T. L. (1995): Decision Making for Leaders: the Analytic Hierarchy Process for Decisions in a Complex World. - RWS Publications, Pittsburgh.

[69] Saner, G., Yucel, B., Yercan, M., Karaturhan, B., Engindeniz, S., Cukur, F., Koseoglu, M. (2011): Organik ve Konvansiyonel Bal Uretiminin Teknik ve Ekonomik Yonden Gelistirilmesi ve Alternatif Pazar Olanakları Uzerine Bir Arastırma: Izmir ili Kemalpasa Ilcesi Ornegi (Uretici-Tuketici-Firma). - TEPGE Yayin No:195, Kasim, Ankara.

[70] Sanova, P., Svobodová, J., Hrubcová, B. (2017): Segmentation of Honey Buyers' Behaviour by Conjoint Analysis. - Scientia Agriculturae Bohemica 48(1): 55-62. DOİ: 10.1515/sab-2017-0008.

[71] Scholl, A., Manthey, L., Helm, R., Steıner, M. (2005): Solving Multiattribute Design Problems with Analytic Hierarchy Process and Conjoint Analysis: An Empirical Comparison. - European Journal of Operational Research 164: 760-777.

[72] Schomoldt, D. L. Peterson, R. L. Smith, R. L. (1995): The Analytic Hierarchy Process And Participatory Decision Making. - Proceedings Of The 4th International Symposium On Advanced Technology In Natural Resources.

[73] Smith, S. (1999): The Concepts of Conjoint Analysis. - http://www. marketing.byu.edu/thml/pages/tutorals/conjoint.htm. Access: 01.03.2017.

[74] Sen, G., Gungor, E. (2018): Endustriyel agaclandirmalar icin en uygun tur seciminde analitik hiyerarsi sureci yonteminin kullanılması: Kastamonu Ili Ornegi. - Turkish Journal of Forestry 19(1): 63-75. DOI: 10.18182/tjf.403922 
[75] TAB (2017): 2017 Yili Bal Uretim Degerleri. - Turkey Beekeepers Association. http://www.tab.org.tr. Access: 14.01.2018.

[76] TBMM (2010): 2010 Y1l Nufus Sayim Sonuclari ve Orman Koylusu Say1lari. http://www2.tbmm.gov.tr/d23/7/7-14296c.pdf. Access: 19.09.2015.

[77] Tutkun, E., Bosgelmez, A. (2003): Bal Zararlisi ve Hastaliklari Teshis ve Tedavi Yontemleri. - Bizim Buro Basimevi, Ankara.

[78] TUIK (2017): Aricilik Istatistikleri. - http://www.tuik.gov.tr. Access: 11.01.2018.

[79] Wheelen, T. L., Hunger, J. D. (1995): Strategic Management and Business Policy (5th Edition). - Addison Wesley, Reading, MA.

[80] WWF (2003): Turkiye'nin Dunyaya Armaganlari. - WWF-Turkiye Yayinları, Ankara, WWF, Turkiye.

[81] WWF (2010): Surdurulebilir Turizm Gelisim Stratejisi (KDMP). - Rapor, Andrei Blumer, WWW-Turkiye.

[82] Yakovleva, L. P. (1975): Utilization of Bees for Polunation of Entomophilous Farm Crops in The USSR. - III. Sym. Int. Pollination. Prague, 15-18 May 1974: 199- 208.

[83] Yilmaz, E. (2004): Orman Kaynaklarının Islevsel Bolumlemesine Iliskin Cozumlemeler. - IU Fen Bilimleri Enstitusu, Unpublished PhD Thesis, Istanbul.

[84] Yilmaz, E. (2006): R'WOT Teknigi: Aricilik Sektorunde Katilimci Yaklasim ile Ornek Bir Uygulamasi. - T.C. Cevre ve Orman Bakanlıgı, Dogu Akdeniz Ormancilik Arastırma Mudurlugu, Cevre ve Orman Bakanligı Yayin No: 274, DOA Yayin No: 40, Cesitli Yayin No: 6, 93 sayfa, Tarsus.

[85] Yılmaz, E. (2007): A'WOT Teknigi Kullanarak Katilimci Yaklasimla Proje Degerlendirmesi. - Dogu Akdeniz Ormancilik Arastirma Enstitusu, DOA Dergisi, Say1: 13 . 